\title{
Trends in prevalence and survival of very low birthweight infants, England and Wales: 1983-7
}

\author{
Eva Alberman, Beverley Botting
}

\begin{abstract}
Between 1983 and 1987 over $99 \%$ of all infants born in England and Wales had their birth weights recorded when the birth was registered. Trends in occurrence and one year survival of those who weighed under $1500 \mathrm{~g}$ at birth have been calculated in $100 \mathrm{~g}$ groups, separately for single and multiple births. By 1987 singleton live births in England and Wales who weighed between 700 and $799 \mathrm{~g}$ had a $43 \%$ chance of surviving to 1 year compared with a $32 \%$ chance five years earlier; those who weighed 800 to $899 \mathrm{~g}$ had a $55 \%$ chance compared with $46 \%$. The absolute number of survivors weighing between $\mathbf{5 0 0}$ and $999 \mathrm{~g}$ at birth increased by nearly $\mathbf{5 0 \%}$ between 1983 and 1987, and there was a 30\% increase overall in survivors weighing less than $1500 \mathrm{~g}$.
\end{abstract}

Infants of very low birth weight (less than 1500 g) are of considerable importance because of the large contribution they make to early deaths, the resources required for their care in the neonatal period, and most of all because of their increased risk of long term disability. ${ }^{12}$ Their risk of death and morbidity is closely related to their weight, the risks rising sharply as birth weight falls.

Between 1983 and 1987 over 99\% of all infants born in England and Wales had their birth weight recorded when the birth was registered, so that it is now possible for us to describe trends in occurrence and one year survival in $100 \mathrm{~g}$ groups separately for single and multiple births.

To help in the planning of their care, and the evaluation of the effects of medical intervention on their survival, the present study gives information on the frequency of births under $1500 \mathrm{~g}$ and their mortality.

Department of

Environmental and

Preventive Medicine,

St Bartholomew's

Medical College,

Wolfson Institute

for Preventive

Medicine,

Charterhouse Square,

London EC1M 6BQ

Eva Alberman

Office of Population

Censuses and Surveys,

Medical Statistics

Division

Beverley Botting

Correspondence to:

Professor Alberman.

Accepted 22 May 1991 Registrar of Births, Marriages and Deaths and now complements information given by the parents when the birth is registered. For some years after 1975 birth weight was not completed, particularly for infants who died early, but between 1983 and 1987 it was obtained for over $99 \%$ of all live births. ${ }^{4}$

Data on occurrence and mortality by birth weight has been published regularly in publications from the Office of Population Censuses and Surveys (OPCS) annually but the breakdown has never been finer than 500 g groups. ${ }^{5}$ This paper is confined to infants weighing less than $1500 \mathrm{~g}$ at birth; results are presented in $100 \mathrm{~g}$ groups and for single and multiple births separately. This grouping was prepared for the second full meeting of the International Collaborative Effort on Perinatal and Infant Mortality (ICE). ${ }^{6}$

There are a number of problems in the interpretation of the data. In England and Wales gestational age is obtained for stillbirths but not for live births, and babies that are born dead cannot be registered as stillbirths unless the pregnancy reached 28 completed weeks of gestation. All live births can theoretically be registered regardless of birth weight or gestational age, but-particularly with very preterm birth-there can be differences in opinion about what is considered to be a miscarriage rather than a live birth, or a stillbirth rather than a live birth. The attitudes of professionals towards the age of viability may affect the maturity threshold at which resuscitation is offered, ${ }^{7}$ and there are international differences in the perceptions and regulations governing definitions of viability. ${ }^{89}$

\section{CALCULATION OF RATES}

We have calculated mortality rates for deaths under the age of 1 year in children born in a given calendar year (birth cohort), even if the death occurred in the year after the birth. This was made possible by linking information from registrations of births and of infant deaths. The more conventional method of analysis is to relate the number of deaths in a given period (death cohort) to the births during the same period, even if the death was of a child born before the beginning of the period. Discrepancies between the use of birth and death cohorts are normally small and relate particularly to postneonatal deaths. Both are available from OPCS annual reports but the mortality rates for birth cohorts are not available until a year after those based on death cohorts. 5

Results

TRENDS IN NUMBERS REGISTERED

Table 1 shows the numbers of infants born 
Table 1 Number (\%) of live births weighing < 1500 g. England and Wales 1983-7

\begin{tabular}{|c|c|c|c|c|c|}
\hline Birth weight $(g)$ & 1983 & 1984 & 1985 & 1986 & 1987 \\
\hline $\begin{array}{c}<400 \\
400- \\
500- \\
600- \\
700- \\
800- \\
900- \\
1000- \\
1100- \\
1200- \\
1300- \\
1400-\end{array}$ & $\begin{array}{r}64(0.01) \\
57(0.01) \\
154(0.02) \\
234(0.04) \\
309(0.05) \\
405(0.06) \\
493(0.08) \\
565(0.09) \\
616(0.10) \\
689(0.11) \\
824(0.13) \\
896(0.14)\end{array}$ & $\begin{array}{r}65(0.01) \\
78(0.01) \\
152(0.02) \\
253(0.04) \\
332(0.05) \\
463(0.07) \\
531(0.08) \\
610(0.10) \\
635(0.10) \\
671(0.11) \\
817(0.13) \\
947(0.15)\end{array}$ & $\begin{array}{r}73(0 \cdot 01) \\
68(0 \cdot 01) \\
147(0 \cdot 02) \\
304(0.05) \\
361(0 \cdot 05) \\
409(0 \cdot 06) \\
560(0 \cdot 09) \\
625(0 \cdot 10) \\
690(0 \cdot 11) \\
706(0 \cdot 11) \\
926(0 \cdot 14) \\
1031(0 \cdot 16)\end{array}$ & $\begin{array}{r}82(0.01) \\
66(0.01) \\
178(0.03) \\
336(0.05) \\
400(0.06) \\
477(0.07) \\
526(0.08) \\
654(0.10) \\
680(0.10) \\
813(0.12) \\
822(0.12) \\
1047(0.16)\end{array}$ & $\begin{array}{r}67(0.01) \\
83(0.01) \\
198(0.03) \\
324(0.05) \\
412(0.06) \\
503(0.07) \\
556(0.08) \\
758(0.11) \\
754(0.11) \\
816(0.12) \\
958(0.14) \\
1076(0.16)\end{array}$ \\
\hline $\begin{array}{l}\text { All }<1500 \\
\text { Not known } \\
\text { All live births }\end{array}$ & $\begin{array}{r}5306(0 \cdot 84) \\
865(0 \cdot 14) \\
629134(100)\end{array}$ & $\begin{array}{r}5554(0 \cdot 87) \\
812(0 \cdot 13) \\
636818(100)\end{array}$ & $\begin{array}{r}5900(0.91) \\
868(0 \cdot 13) \\
656417(100)\end{array}$ & $\begin{array}{c}6081(0.91) \\
624(0.09) \\
661018(100)\end{array}$ & $\begin{array}{r}6505(0.95) \\
502(0.07) \\
681511(100)\end{array}$ \\
\hline
\end{tabular}

weighing less than $1500 \mathrm{~g}$ and the percentage they formed of all births from 1983-7. There was a rise of $23 \%$ in the absolute numbers of registered live births of these weights, partly because there was an increase of $8 \%$ in births of all weights and partly because the proportion of all live births who had a birth weight of less than $1500 \mathrm{~g}$ rose from $0.84 \%$ in 1983 to $0.95 \%$ in 1987.

Table 2 gives the numbers by live births and stillbirths, and by single and multiple births. There was an increase of $21 \%$ in the number of live born singletons weighing less than $1500 \mathrm{~g}$ between 1983 and 1987 , and an increase of $28 \%$ in multiple births. With the exception of the very lowest weight groups, the numbers of stillbirths actually fell over the period. Nevertheless, taking live births and stillbirths together, the total number of infants born weighing less than $1500 \mathrm{~g}$ still increased over the period, by $16 \%$ for singleton and $24 \%$ for multiple births. Multiple births account for about one fifth of these very low birthweight babies.

\section{INFANTS OF UNKNOWN BIRTH WEIGHT OR} REPORTED TO HAVE WEIGHED LESS THAN $500 \mathrm{G}$ Table 3 gives the birthweight specific infant mortality rates for birth of less than $1500 \mathrm{~g}$, and for births of unknown weight, separately for the years 1983 to 1987 . In each year the mortality rates of those weighing less than $500 \mathrm{~g}$ are lower than those of babies weighing between 500 and 799 g. Moreover, babies of unknown weight have high infant mortality rates. For singletons these approximate to those of babies who weighed between 1200 and $1299 \mathrm{~g}$ in 1983, and to those who weighed between 1000 and $1099 \mathrm{~g}$

Table 2 (A) Birth weight distribution in 1983 and 1987 for single and multiple births, and live births and stillbirths

\begin{tabular}{|c|c|c|c|c|c|c|c|c|}
\hline \multirow{3}{*}{$\begin{array}{l}\text { Birth } \\
\text { weight } \\
\text { (g) }\end{array}$} & \multicolumn{4}{|l|}{1983} & \multicolumn{4}{|l|}{1987} \\
\hline & \multicolumn{2}{|c|}{ Live births } & \multicolumn{2}{|c|}{ Stillbirths } & \multicolumn{2}{|c|}{ Live births } & \multicolumn{2}{|c|}{ Stillbirths } \\
\hline & Single & Multiple & Single & Multiple & Single & Multiple & Single & Multiple \\
\hline $\begin{array}{c}<500 \\
500- \\
600- \\
700- \\
800- \\
900- \\
1000- \\
1100- \\
1200- \\
1300- \\
1400-\end{array}$ & $\begin{array}{r}98 \\
117 \\
183 \\
261 \\
339 \\
403 \\
464 \\
515 \\
576 \\
653 \\
677\end{array}$ & $\begin{array}{r}23 \\
37 \\
51 \\
48 \\
66 \\
90 \\
101 \\
101 \\
113 \\
171 \\
219\end{array}$ & $\begin{array}{r}36 \\
26 \\
58 \\
88 \\
90 \\
106 \\
133 \\
121 \\
105 \\
116 \\
104\end{array}$ & $\begin{array}{r}20 \\
6 \\
8 \\
12 \\
11 \\
11 \\
11 \\
10 \\
20 \\
9 \\
13\end{array}$ & $\begin{array}{l}126 \\
138 \\
266 \\
335 \\
412 \\
427 \\
633 \\
625 \\
633 \\
758 \\
848\end{array}$ & $\begin{array}{r}24 \\
60 \\
58 \\
77 \\
91 \\
129 \\
125 \\
129 \\
183 \\
200 \\
228\end{array}$ & $\begin{array}{r}59 \\
38 \\
58 \\
80 \\
72 \\
97 \\
111 \\
95 \\
100 \\
96 \\
97\end{array}$ & $\begin{array}{r}16 \\
6 \\
11 \\
11 \\
7 \\
6 \\
6 \\
11 \\
19 \\
18 \\
13\end{array}$ \\
\hline $\begin{array}{l}\text { All }<1500 \\
\text { Not known }\end{array}$ & $\begin{array}{r}4286 \\
810\end{array}$ & $\begin{array}{r}1020 \\
55\end{array}$ & $\begin{array}{r}983 \\
35\end{array}$ & $\begin{array}{r}131 \\
17\end{array}$ & $\begin{array}{r}5201 \\
474\end{array}$ & $\begin{array}{r}1304 \\
28\end{array}$ & $\begin{array}{r}903 \\
22\end{array}$ & $\begin{array}{r}124 \\
11\end{array}$ \\
\hline
\end{tabular}

(B) Percentage change from 1983 to 1987 for single and multiple births, and live births and stillbirths

\begin{tabular}{|c|c|c|c|c|c|c|}
\hline \multirow{2}{*}{$\begin{array}{l}\text { Birth } \\
\text { weight } \\
\text { (g) }\end{array}$} & \multicolumn{2}{|c|}{ Live births } & \multicolumn{2}{|c|}{ Stillbirths } & \multirow{2}{*}{$\begin{array}{l}\text { All } \\
\text { single }\end{array}$} & \multirow{2}{*}{$\begin{array}{l}\text { All } \\
\text { multiple }\end{array}$} \\
\hline & Single & Multiple & Single & Multiple & & \\
\hline $\begin{array}{c}<500 \\
500- \\
600- \\
700- \\
800- \\
900- \\
1000- \\
1100- \\
1200- \\
1300- \\
1400-\end{array}$ & $\begin{array}{r}29 \\
18 \\
45 \\
28 \\
22 \\
6 \\
36 \\
21 \\
10 \\
16 \\
25\end{array}$ & $\begin{array}{r}4 \\
62 \\
14 \\
60 \\
38 \\
43 \\
24 \\
28 \\
62 \\
17 \\
4\end{array}$ & $\begin{array}{r}64 \\
46 \\
0 \\
-9 \\
-20 \\
-8 \\
-17 \\
-21 \\
-5 \\
-17 \\
-7\end{array}$ & $\begin{array}{r}-20 \\
0 \\
38 \\
-8 \\
-36 \\
-45 \\
-45 \\
10 \\
-5 \\
100 \\
0\end{array}$ & $\begin{array}{r}38 \\
23 \\
34 \\
19 \\
13 \\
3 \\
25 \\
13 \\
8 \\
11 \\
21\end{array}$ & $\begin{array}{r}-7 \\
53 \\
17 \\
47 \\
27 \\
34 \\
17 \\
26 \\
52 \\
21 \\
4\end{array}$ \\
\hline $\begin{array}{l}\text { All <1500 } \\
\text { Not known }\end{array}$ & $\begin{array}{r}21 \\
-41\end{array}$ & $\begin{array}{r}28 \\
-49\end{array}$ & $\begin{array}{r}-8 \\
-37\end{array}$ & $\begin{array}{r}-5 \\
-35\end{array}$ & $\begin{array}{r}16 \\
-46\end{array}$ & $\begin{array}{r}24 \\
-46\end{array}$ \\
\hline
\end{tabular}


in 1987. For multiple births the mortality of those of unknown weight is consistently higher than the average for all those known to have weighed less than $1500 \mathrm{~g}$.

Between 1983 and 1987 there was a decrease in the total number of infants of unknown birth weight from 917 to 535 (table 2). These almost certainly include some of low birth weight, as indicated by the high proportion of multiple births $(6 \%$ of live births and $33 \%$ of stillbirths in $1987)$ and their high infant mortality rates. The proportion whose birth weight was unknown is highest among stillbirths, being $1 \cdot 0 \%$ of all stillbirths in 1987 compared with $0.1 \%$ of live births, and among multiple births, $4 \%$ among stillbirths, $0 \cdot 2 \%$ among live multiple births.

The increase in the proportion of very low birthweight babies born between 1983 and 1987 is not, however, just an artefact caused by a decrease in the proportion for whom the weight was unknown. Even if all those of unknown weight are included with those known to have weighed less than $1500 \mathrm{~g}$ there would still have been an increase of $10 \%$ in the proportion of very low birthweight babies born between 1983 and 1987 compared with $8 \%$ in all births.

There must also be some doubt about the accuracy of the birth weights of live born babies registered as weighing less than $500 \mathrm{~g}$, whose mortality rates are lower than those of slightly heavier babies. The number of such births rose from 121 to 150 between 1983 and 1987, an increase of over $20 \%$. Analysis of data gathered since 1987 suggests that the increase in the use of metric birth weights may be increasing the number of transcription errors, particularly those which result in babies of 3000 or $4000 \mathrm{~g}$ being recorded as weighing 300 or $400 \mathrm{~g}$. It is likely that some of these extremely low weights have been misclassified in this way, and may be contributing towards the increase in numbers of those registered as of very low birth weight, although the numbers are too small to have a serious effect.

TRENDS IN INFANT MORTALITY RATES

The most important feature shown in table 3 is the continuing reduction in birthweight specific infant mortality among singletons over the period, although the annual patterns in the individual weight groups from $500 \mathrm{~g}$ upwards are slightly inconsistent. The changes are summa- rised in fig 1 by averaging rates for the first three, and last two, years of the period. There is a fall in infant mortality in each $100 \mathrm{~g}$ weight group, the biggest falls being in those who weighed between 700 and $900 \mathrm{~g}$. The pattern for multiple births is different (fig 2) and shows no consistent improvement.

Table 3 also shows that, for the lowest birth weights, multiple births have higher mortality rates than singletons. This pattern is reversed at higher weights, the turning point varying by year, but becoming pronounced and quite consistent at weights of $1300 \mathrm{~g}$ or more.

\section{RATIO OF STILLBIRTHS : INFANT DEATHS}

At the lower tail of the birth weight distribution the problem of definition of viability means that the ratio of stillbirths: infant deaths is affected, because live births but not fetal deaths can be registered under 28 weeks' gestational age. Table 4 shows that in each of the years concerned at birth weights of less than $1000 \mathrm{~g}$,

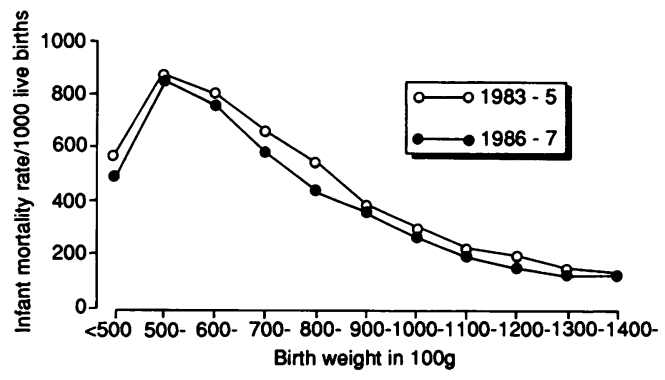

Figure 1 Averaged infant mortality rates for singleton births weighing $<1500 \mathrm{~g}$ for 1983-5 and 1986-7.

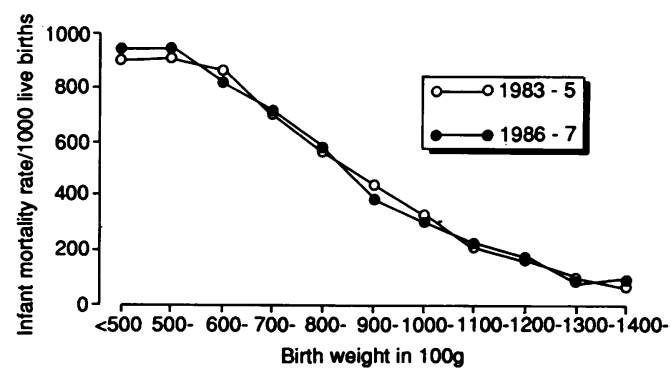

Figure 2 Averaged infant mortality rates for multiple births weighing $<1500 \mathrm{~g}$ for $1983-5$ and $1986-7$.

Table 3 Trends in infant mortality rates/1000 live births of very low birthweight infants: England and Wales 1983-7

\begin{tabular}{|c|c|c|c|c|c|c|c|c|c|c|}
\hline \multirow{2}{*}{$\begin{array}{l}\text { Birth } \\
\text { weight } \\
\text { (g) }\end{array}$} & \multicolumn{2}{|l|}{1983} & \multicolumn{2}{|l|}{1984} & \multicolumn{2}{|l|}{1985} & \multicolumn{2}{|l|}{1986} & \multicolumn{2}{|l|}{1987} \\
\hline & Singleton & Multiple & Singleton & Multiple & Singleton & Multiple & Singleton & Multiple & Singleton & Multiple \\
\hline $\begin{array}{c}<500 \\
500- \\
600- \\
700- \\
800- \\
900- \\
1000- \\
1100- \\
1200- \\
1300- \\
1400-\end{array}$ & $\begin{array}{l}592 \\
897 \\
858 \\
678 \\
540 \\
427 \\
349 \\
239 \\
226 \\
167 \\
123\end{array}$ & $\begin{array}{r}783 \\
1000 \\
843 \\
771 \\
530 \\
500 \\
366 \\
218 \\
186 \\
82 \\
82\end{array}$ & $\begin{array}{l}565 \\
849 \\
787 \\
666 \\
538 \\
366 \\
285 \\
216 \\
168 \\
142 \\
128\end{array}$ & $\begin{array}{r}964 \\
939 \\
863 \\
680 \\
670 \\
412 \\
286 \\
259 \\
229 \\
108 \\
28\end{array}$ & $\begin{array}{l}530 \\
866 \\
772 \\
643 \\
555 \\
347 \\
249 \\
223 \\
189 \\
123 \\
136\end{array}$ & $\begin{array}{r}961 \\
800 \\
889 \\
672 \\
508 \\
405 \\
308 \\
161 \\
86 \\
109 \\
81\end{array}$ & $\begin{array}{l}458 \\
899 \\
738 \\
598 \\
439 \\
397 \\
247 \\
188 \\
162 \\
125 \\
135\end{array}$ & $\begin{array}{r}933 \\
959 \\
783 \\
710 \\
598 \\
369 \\
321 \\
220 \\
144 \\
81 \\
114\end{array}$ & $\begin{array}{l}532 \\
804 \\
793 \\
567 \\
449 \\
323 \\
289 \\
206 \\
155 \\
128 \\
111\end{array}$ & $\begin{array}{l}958 \\
933 \\
862 \\
727 \\
571 \\
403 \\
288 \\
225 \\
202 \\
80 \\
61\end{array}$ \\
\hline $\begin{array}{l}\text { All }<1500 \\
\text { Not known } \\
\text { All weights }\end{array}$ & $\begin{array}{l}340 \\
204 \\
9 \cdot 38\end{array}$ & $\begin{array}{l}321 \\
436 \\
40 \cdot 7\end{array}$ & $\begin{array}{l}311 \\
207 \\
8 \cdot 52\end{array}$ & $\begin{array}{l}341 \\
442 \\
41 \cdot 6\end{array}$ & $\begin{array}{l}302 \\
156 \\
8 \cdot 78\end{array}$ & $\begin{array}{l}299 \\
565 \\
39 \cdot 2\end{array}$ & $\begin{array}{l}265 \\
178 \\
8 \cdot 35\end{array}$ & $\begin{array}{l}324 \\
407 \\
45 \cdot 3\end{array}$ & $\begin{array}{l}289 \\
221 \\
8 \cdot 36\end{array}$ & $\begin{array}{l}323 \\
500 \\
42 \cdot 7\end{array}$ \\
\hline
\end{tabular}


the ratio of stillbirths:infants deaths was smaller than among those weighing between 1000 and $1499 \mathrm{~g}$.

AGE AT DEATH

Babies weighing less than $1500 \mathrm{~g}$ often die at very young ages, so that they contribute disproportionately to very early deaths. In 1987 , $27 \%$ of all infant singleton deaths had weighed less than $1500 \mathrm{~g}$ at birth, but only $0.8 \%$ of singleton live births had been of this weight. Fifty four per cent of all singleton live born babies that died during the first 30 minutes had weighed less than $1500 \mathrm{~g}$. Although this proportion fell with increasing age at death, there was an excess of babies of this weight even in the deaths occurring between 9 months and 1 year,

Table 4 Numbers of infant deaths and stillbirths weighing less than $1500 \mathrm{~g}$-multiple plus singleton births: England and Wales 1983-7

\begin{tabular}{llllll}
\hline Year & \multicolumn{2}{l}{ Birth weight $(\mathrm{g})$} & & \multicolumn{2}{l}{ Stillbirths } \\
\cline { 2 - 3 } \cline { 5 - 6 } & \multicolumn{2}{l}{ Infant deaths } & & \\
\cline { 2 - 3 } & $<1000$ & $1000-1499$ & & $<1000$ & $1000-1499$ \\
\hline 1983 & 1067 & 719 & & 472 & 642 \\
1984 & 1109 & 650 & & 490 & 612 \\
1985 & 1112 & 668 & & 499 & 580 \\
1986 & 1173 & 663 & 479 & 621 \\
1987 & 1191 & 733 & 461 & 566 \\
\hline
\end{tabular}

of which $6 \%$ had weighed less than $1500 \mathrm{~g}$. The pattern for multiple births was similar but even more pronounced. Sixty eight per cent of all infant deaths of babies from multiple births in 1987 had been reported as weighing less than $1500 \mathrm{~g}$ at birth, and $92 \%$ of deaths among multiple births that occurred within $\mathbf{3 0}$ minutes of birth had been of this weight, compared with a third of deaths of multiple births between 9 months and 1 year of age.

Table 5 shows the proportions by age at death of all those weighing less than $1500 \mathrm{~g}$ at birth in 1983 and 1987. The proportion of all deaths that happened during the postneonatal period rose slightly from $11.8 \%$ in 1983 to $12.8 \%$ in 1987 in singletons, and from $11 \cdot 6 \%$ to $12 \cdot 3 \%$ in multiple births.

TRENDS IN NUMBERS OF INFANTS SURVIVING

Between 1983 and 1987 the rise in the registered occurrences, together with the improvement in survival, led to an increased number of very low birthweight survivors at 1 year (table 6). Overall, the absolute number of singleton survivors reported as having a birth weight of less than $1500 \mathrm{~g}$ increased by $31 \%$ between 1983 and 1987 , and that of multiple births by $27 \%$. The number of survivors weighing between 500 and $999 \mathrm{~g}$ at birth increased even more, singletons by $46 \%$ and multiple births by $58 \%$.

Table 5 Time of death by birth weight and multiplicity, England and Wales: 1983 and 1987

\begin{tabular}{|c|c|c|c|c|c|c|c|c|}
\hline \multirow[t]{3}{*}{ Infant deaths } & \multicolumn{4}{|l|}{1983} & \multicolumn{4}{|l|}{1987} \\
\hline & \multicolumn{2}{|c|}{ Singleton } & \multicolumn{2}{|c|}{ Multiple } & \multicolumn{2}{|c|}{ Singleton } & \multicolumn{2}{|c|}{ Multiple } \\
\hline & No & $\%$ & No & $\%$ & No & $\%$ & No & $\%$ \\
\hline $\begin{array}{l}\text { All weights } \\
\text { All }<1500 \mathrm{~g}\end{array}$ & $\begin{array}{l}5786 \\
1459\end{array}$ & $\begin{array}{r}100 \\
25\end{array}$ & $\begin{array}{l}513 \\
327\end{array}$ & $\begin{array}{r}100 \\
64\end{array}$ & $\begin{array}{l}5573 \\
1503\end{array}$ & $\begin{array}{r}100 \\
27\end{array}$ & $\begin{array}{l}620 \\
421\end{array}$ & $\begin{array}{r}100 \\
68\end{array}$ \\
\hline All $<1500 \mathrm{~g}$ & 1459 & 100 & 327 & 100 & 1503 & 100 & 421 & 100 \\
\hline $\begin{array}{l}30 \text { Minutes } \\
-1 \text { Day } \\
1-6 \text { Days } \\
7-27 \text { Days }\end{array}$ & $\begin{array}{r}94 \\
622 \\
394 \\
176\end{array}$ & $\begin{array}{r}6 \\
43 \\
27 \\
12\end{array}$ & $\begin{array}{r}16 \\
142 \\
92 \\
39\end{array}$ & $\begin{array}{r}5 \\
43 \\
28 \\
12\end{array}$ & $\begin{array}{l}114 \\
604 \\
378 \\
215\end{array}$ & $\begin{array}{r}8 \\
40 \\
25 \\
14\end{array}$ & $\begin{array}{r}36 \\
145 \\
130 \\
58\end{array}$ & $\begin{array}{l}9 \\
34 \\
31 \\
14\end{array}$ \\
\hline All neonatal deaths & 1286 & 88 & 289 & 88 & 1311 & 87 & 369 & 88 \\
\hline $\begin{array}{l}\text { 28 Days-2 months } \\
\text { 3-5 Months } \\
6-8 \text { Months } \\
9-11 \text { Months }\end{array}$ & $\begin{array}{l}91 \\
41 \\
31 \\
10\end{array}$ & $\begin{array}{l}6 \\
3 \\
2 \\
1\end{array}$ & $\begin{array}{r}18 \\
16 \\
2 \\
2\end{array}$ & $\begin{array}{r}6 \\
5 \\
1 \\
<1\end{array}$ & $\begin{array}{l}85 \\
65 \\
32 \\
10\end{array}$ & $\begin{array}{l}6 \\
4 \\
2 \\
1\end{array}$ & $\begin{array}{r}22 \\
17 \\
8 \\
5\end{array}$ & $\begin{array}{l}5 \\
4 \\
2 \\
1\end{array}$ \\
\hline All postneonatal deaths & 173 & 12 & 38 & 12 & 192 & 13 & 52 & 12 \\
\hline
\end{tabular}

Table 6 Birth cohort survivors at 1 year by birth weight, England and Wales: 1983-7

\begin{tabular}{|c|c|c|c|c|c|c|c|c|c|c|}
\hline \multirow{3}{*}{$\begin{array}{l}\text { Birth } \\
\text { weight } \\
\text { (g) }\end{array}$} & \multicolumn{10}{|c|}{ No of survivors at 1 year* } \\
\hline & \multicolumn{2}{|l|}{1983} & \multicolumn{2}{|l|}{1984} & \multicolumn{2}{|l|}{1985} & \multicolumn{2}{|l|}{1986} & \multicolumn{2}{|l|}{1987} \\
\hline & Singleton & Multiple & Singleton & Multiple & Singleton & Multiple & Singleton & Multiple & Singleton & Multiple \\
\hline $\begin{array}{r}<500- \\
500- \\
600- \\
700- \\
800- \\
900- \\
1000- \\
1100- \\
1200- \\
1300- \\
1400-\end{array}$ & $\begin{array}{r}40 \\
12 \\
26 \\
84 \\
156 \\
231 \\
302 \\
392 \\
446 \\
544 \\
594\end{array}$ & $\begin{array}{r}5 \\
0 \\
8 \\
11 \\
31 \\
45 \\
64 \\
79 \\
92 \\
157 \\
201\end{array}$ & $\begin{array}{r}50 \\
18 \\
43 \\
94 \\
172 \\
275 \\
361 \\
410 \\
460 \\
582 \\
667\end{array}$ & $\begin{array}{r}1 \\
2 \\
7 \\
16 \\
30 \\
57 \\
75 \\
83 \\
91 \\
124 \\
117\end{array}$ & $\begin{array}{r}54 \\
15 \\
55 \\
106 \\
153 \\
293 \\
401 \\
440 \\
469 \\
651 \\
720\end{array}$ & $\begin{array}{r}1 \\
7 \\
7 \\
21 \\
32 \\
66 \\
63 \\
104 \\
117 \\
163 \\
182\end{array}$ & $\begin{array}{r}64 \\
13 \\
70 \\
133 \\
216 \\
255 \\
394 \\
449 \\
541 \\
569 \\
693\end{array}$ & $\begin{array}{r}2 \\
2 \\
15 \\
20 \\
37 \\
65 \\
89 \\
99 \\
143 \\
158 \\
218\end{array}$ & $\begin{array}{r}59 \\
27 \\
55 \\
145 \\
227 \\
289 \\
450 \\
496 \\
535 \\
661 \\
754\end{array}$ & $\begin{array}{r}1 \\
4 \\
8 \\
21 \\
39 \\
77 \\
89 \\
100 \\
146 \\
184 \\
214\end{array}$ \\
\hline All $<1500$ & 2827 & 693 & 3132 & 603 & 3357 & 763 & 3397 & 848 & 3698 & 883 \\
\hline
\end{tabular}

${ }^{*}$ Calculated as number of live births minus infant deaths. 


\section{Discussion}

The aim of this report was to make data available from a new national data set that show trends in the incidence and survival of infants weighing under $1500 \mathrm{~g}$ at birth. The main findings were an increase in the absolute number and the incidence of these births, and a fall in their infant mortality.

Some of the observed rise in the proportion of babies of very low birth weight from $0.84 \%$ in 1983 to $0.95 \%$ in 1987 may be the result of an increase in the proportion of triplets and higher order multiple births ${ }^{10}$; some is probably the result of a change in clinical perception, shifting the reported outcomes from non-registrable miscarriages to registered births; and some is the result of a decrease in the proportion for whom birth weight was not reported. Additionally, there is a suggestion that there may be a shift from stillbirths to live births, but in the absence of information about registration practices of very low weight stillbirths this will be difficult to prove. These issues were recently discussed in some detail at a meeting of the International Collaborative Effort into Perinatal and Infant Mortality. ${ }^{6}$ It was thought that for complete reporting there should be a legal limit of viability defined in weeks of gestation, set at a point some weeks earlier than the maturity at which registrations may be expected to be reliable.

The next point to be considered is the evidence about the validity of reported weights at the lowest birth weights. There have long been problems caused by the dual use of imperial and metric measures of birth weight, which lead to digit preference when half or quarter pounds are converted to grams. Moreover, as stated earlier, this may also be leading to errors in placing the decimal point, which results in weights of 3000 or $4000 \mathrm{~g}$ being reported as 300 or $400 \mathrm{~g}$. Although the numbers may be small such mistakes may have considerable effects on national statistics in this weight range. These are errors that should be eliminated by careful quality checks and the availability of data about gestational ages. The number of babies of unknown weights, which is often biased by a excess of stillbirths or infant deaths, should also be considered in the interpretation of changes in mortality rates over time.
Overall, however, during the years considered, the quality of data seems good enough to confirm the increase in survival to 1 year for babies of these very low weights, particularly for singletons weighing between 700 and $900 \mathrm{~g}$. By 1987 a singleton live birth weighing between 700 and $799 \mathrm{~g}$ had a $43 \%$ chance of surviving to 1 year compared with a $32 \%$ chance five years earlier; one weighing 800 to $899 \mathrm{~g}$ had a $55 \%$ chance compared with $46 \%$ in 1983 . The lack of improvement in survival of multiple births is probably related to the sharp increase in the number of the particularly high risk triplets and higher order multiple births. ${ }^{10}$

The number of survivors, both single and multiple, who weighed between 500 and $999 \mathrm{~g}$ at birth increased by nearly $50 \%$ between 1983 and 1987. Such babies are of course also at high risk of morbidity, and the increased number underlines the need for ongoing surveillance of their outcome, and for the maintenance of high quality data about the circumstances of their birth and their maturity.

We gratefully acknowledge the Office of Population Censuses and Surveys, which provided the data. We also thank Karen Dunnell for helpful advice.

1 Alberman E, Evans SJW. The epidemiology of prematurity: aetiology, prevalence and outcome. Annales Nestle 1989;47: 69-88.

2 Drummond $M$. Review of evaluative studies of intensive care for very low birthweight infants-social and economic aspects. In: Kaminski M, Breart G, Buekens P, Huisjes Ho, Mcllwaine G, Selbmann H-C, eds. Perinatal care 265-78.

3 Pharoah POD, Alberman ED. Mortality of low birthweight infants in England and Wales 1953-1979. Arch Dis Child infants in Eng

4 Office of Population Censuses and Surveys. Birthweight statistics. Monitor DH3 80/1 London: HMSO, 1980.

5 Office of Population Censuses and Surveys. Mortality statistics; perinatal and infant: social and biological factors. Series DH3. London: HMSO, annual.

6 USA National Center for Health. International collaborative effort on perinatal and infant mortality. Washington, DC : USA National Center for Health Statistics (in press)

7 Fenton AC, Field DG, Mason E, Clarke M. Attitudes to viability of preterm infants and their effects on figures for perinatal mortality. $B M \mathcal{F}$ 1990;300:434-6.

8 European Community collaborative study of outcome of pregnancy between 22 and 28 weeks' gestation. Working group on the very low birthweight infant. Lancet 1990;336: group

9 Blondel B. Registration of births of very low birthweight infants. Lancet 1990;336:1317-8.

10 Botting BJ, MacDonald Davies I, Macfarlane AJ. Recent trends in the incidence of multiple births and associated mortality. Arch Dis Child 1987;62:941-50. 